\title{
A Recent Development of the Spatial Disparity of Housing Prices in Iceland and Its Underlying Economic Causes
}

\author{
Vífill Karlsson \\ The Faculty of Business and Science \\ University of Akureyri \\ Solborg/Nordurslod \\ 600 Akureyri, Iceland \\ Regional Development Office of West-Iceland \\ Bjarnarbraut 8, 310 Borgarnes \\ Iceland \\ E-mail: vifill@vesturland.is
}

Received: August 4, 2015

doi:10.5296/ijrd.v2i2.8102
Accepted: September 28, 2015 Published: October 28, 2015

URL: http://dx.doi.org/10.5296/ijrd.v2i2.8102

\begin{abstract}
In this paper, the author examines the development of the spatial distribution of housing prices. Due to consumer preferences for access over amenity value, there is a spatial disparity of housing prices. According to Alonso's extension of von Tünen's theory, the relationship between housing prices in urban and rural areas tends to follow certain principles. This relationship is more often negative than positive, i.e. the price of a standardized unit of housing declines with increasing distance from a central business district (CBD). It has been documented that this relationship is negative for Iceland, as well as in many regions of other countries. It is argued here that this relationship has become increasingly marked in Iceland, most likely due to the altered household preferences and structural changes. A macro panel data set from Iceland will be used, representing several essential variables of the residential housing market for 79 municipalities in Iceland from 1981 to 2006.
\end{abstract}

Keywords: Housing prices, Bid-rent curve, Distance gradient, Agglomeration economies, Amenity values 


\section{Introduction}

Historically, housing prices in Iceland have fluctuated significantly: They were stable in the early 1990s, rose rapidly in the late 1990s and early 2000s, and have now decreased substantially, since reaching an all-time high in 2007. This paper looks at how the spatial disparity of housing prices has developed in Iceland, and the underlying economic causes.

Many have argued that the spatial disparity of housing prices tends to follow a certain structure (Fujita, 1989; Fujita \& Thisse, 2002, pp. 78-91; McCann, 2001). The pattern is generally a negative distance gradient - that is, price declines with distance from a central business district (CBD). The slope of the so-called bid-rent curve presents this relationship. The existence and shape of the bid-rent curve is dependent on consumers' preferences for access over amenities, where the urban areas are richer in access than rural areas and rural areas richer in positive amenities. Here, access includes proximity to a to a variety of goods, services and jobs; positive amenities consist of natural resources, public services and social activities; while negative amenities or dis-amenities comprise local phenomena, attributes, incidents or threats, including crime and pollution, that decrease the welfare of the local population without compensation. If access becomes more valuable than amenities, the curve steepens, reflecting increased spatial disparity of housing prices in favour of urban housing prices.

Therefore, the research question of this article addresses whether the shape of a curve based on the framework of the bid-rent curve, has changed recently. If the slope of the curve increases significantly between the relevant periods - when corrected for other possible explanations for spatial disparity of housing prices, such as household income and housing characteristics - evidence will be found, ceteris paribus, of increased household preference for access over amenity values in a small city, the capital of Iceland.

The current study differs from previous work in four ways. Firstly, none of the earlier studies have tried to detect the value of access in as small a city as Reykjavik, the capital of Iceland. Secondly, no previous research focuses on a community as sparsely populated as Iceland. Thirdly, the data sample of the present study covers a whole country. Finally, the country studied in the current research, an isolated island is, to some extent, a geographically unusual market in the literature on urban economics but, nevertheless, a case of special interest in this context. This will be discussed in detail later.

The organization of the study is as follows: Section 1 presents the introduction and a description of the paper's purpose. Section 2 introduces the geography and economy of Iceland. Section 3 contains a theoretical discussion of the model and several other possible approaches, while Section 4 describes the data, its origins and, construction and processing, as well as definitions. Section 5 contains the analysis and results, and Section 6 comprises a summary and concluding remarks.

\section{Iceland}

Iceland is an $103,000 \mathrm{~km}^{2}$ island in the North Atlantic Ocean. The population reached 300,000 in January 2006, and there are approximately 100 towns and villages scattered along 
the coastline. Close to 121,000 of the inhabitants live in the capital, Reykjavík, and 209,000 live in the larger capital area.

The main industries of Iceland have historically been fishery and farming. During the $20^{\text {th }}$ century knowledge-based industry was small but growing gradually. However, during the latest economic expansion, this, in turn, expanded as the growth of highly skilled employment suggests. Iceland's export industries, are located in various coastal regions. This includes, in order of importance of national export income, the energy intensive sector such as aluminium smelters and a ferro silicon plant, the fisheries, tourism, and agriculture. Note, however, that the energy intensive industry is in the vicinity of the capital area, apart from initiatives begun in 2005, and the capital area is strong in tourism.

There are four large production plants in Iceland which can be classified as energy intensive industry - three aluminium smelters and a plant producing ferro silicon. The first aluminium smelter was built and finished on the fringe of the capital area in 1969 and a ferro silicon production plant was constructed on the west coast in 1979. Another aluminium smelter was established on the west coast, adjacent to the ferro silicon plant in 1998. The construction of an aluminium smelter began on the east coast in 2005. According to Statistics Iceland, the export of aluminium and ferro silicon products has risen from 154 thousand tonnes in 1990 to 409 thousand tonnes in 2005.

Tourism has been a growing industry as well. Foreign tourist arrivals were 141 thousand in 1990 and 374 thousand in 2005. According to numbers for overnight stays of tourists, more than $50 \%$ of all tourists stay in the capital area. The east coast, the north east, and the south coast receive in excess of $10 \%$ of all tourists each; the west coast and the southern peninsula about 5\% each, and the north west coast and the western fjords, about $2.5 \%$ each. These are rough estimates but they remain relatively stable from year to year. Thus, the tourist industry is a growing business in Iceland but geographically heterogeneous as indicated by the figures above. All numbers regarding tourism come from Statistics Iceland.

In the 1960 s, prior to the first energy intensive production plant in Iceland, about $90 \%$ of Iceland's export value came from fisheries (Jónsson \& Magnússon, 1997). Today, however, this figure is approximately $30 \%$ while both energy intensive industry is a slightly larger sources of export income and tourism slightly less. 


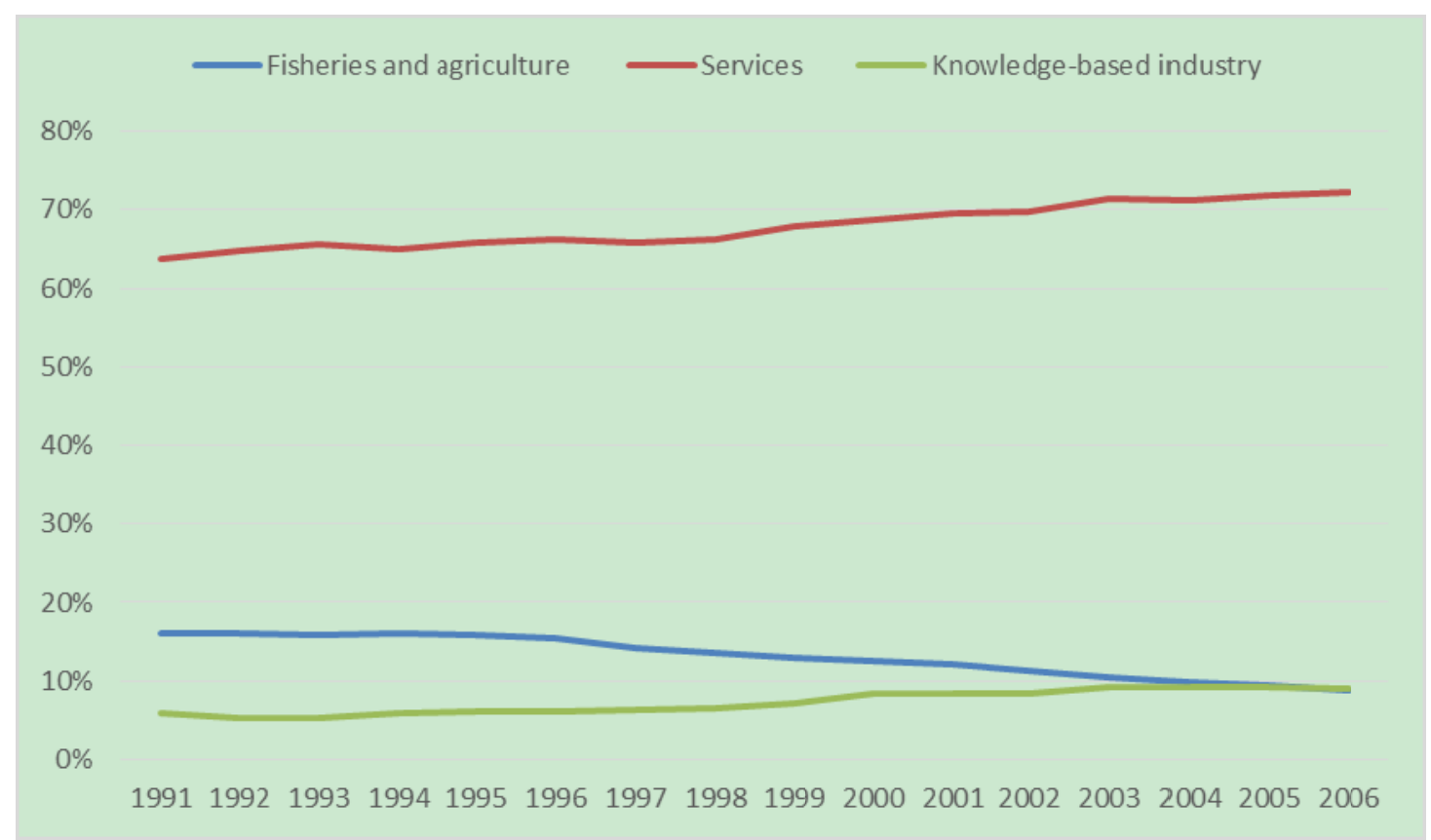

Figure 1. Selective industries share in total employment in Iceland from 1991-2006

Source: Statistics Iceland

Most export industry in rural areas of Iceland is based on natural resources. Due to capacity constraints, especially in fishing, growth potential in resource-based industries is limited, whereas the growth of knowledge-based industries and services has been rapid (Figure 1), making the labour market more attractive in the capital area than in outlying regions.

According to data from Statistics Iceland and Registers Iceland, the population is still rising faster in the capital area of Iceland than in the rural area, despite increasingly higher housing prices in the capital area. The population of the capital area grew by more than $20 \%$ in a period including the latest economic expansion (1994-2006), even though housing prices in the capital area were approximately 50\% higher than in rural areas, with the price differential growing during rapid economic expansion. Housing prices increased by $97.9 \%$ in the capital area in the period $1994-2006$, but only by $67.8 \%$ in rural areas; $62 \%$ of the population lived in the capital area at the end of 2006.

The main explanation for this development is probably the shift towards knowledge-based industries in Iceland and services, mainly located in the capital region. The latest economic expansion in Iceland was more intensively driven by knowledge-based industry than former expansions. The data from Statistics Iceland show that the employment weight increased by $50 \%$ in the most knowledge driven categories in the present classification; that is, financial, real estate, renting and business activities, grew from 5.9\% to 9.0\% between 1991 and 2006, while the weight of primary and fish processing industry decreased by $55 \%$ (Figure 1 ). In this period, total employment rose by $24 \%$ in Iceland. Note that the weight of other service activities grew by $13 \%$, a sector which is more knowledge intensive than primary industry. 


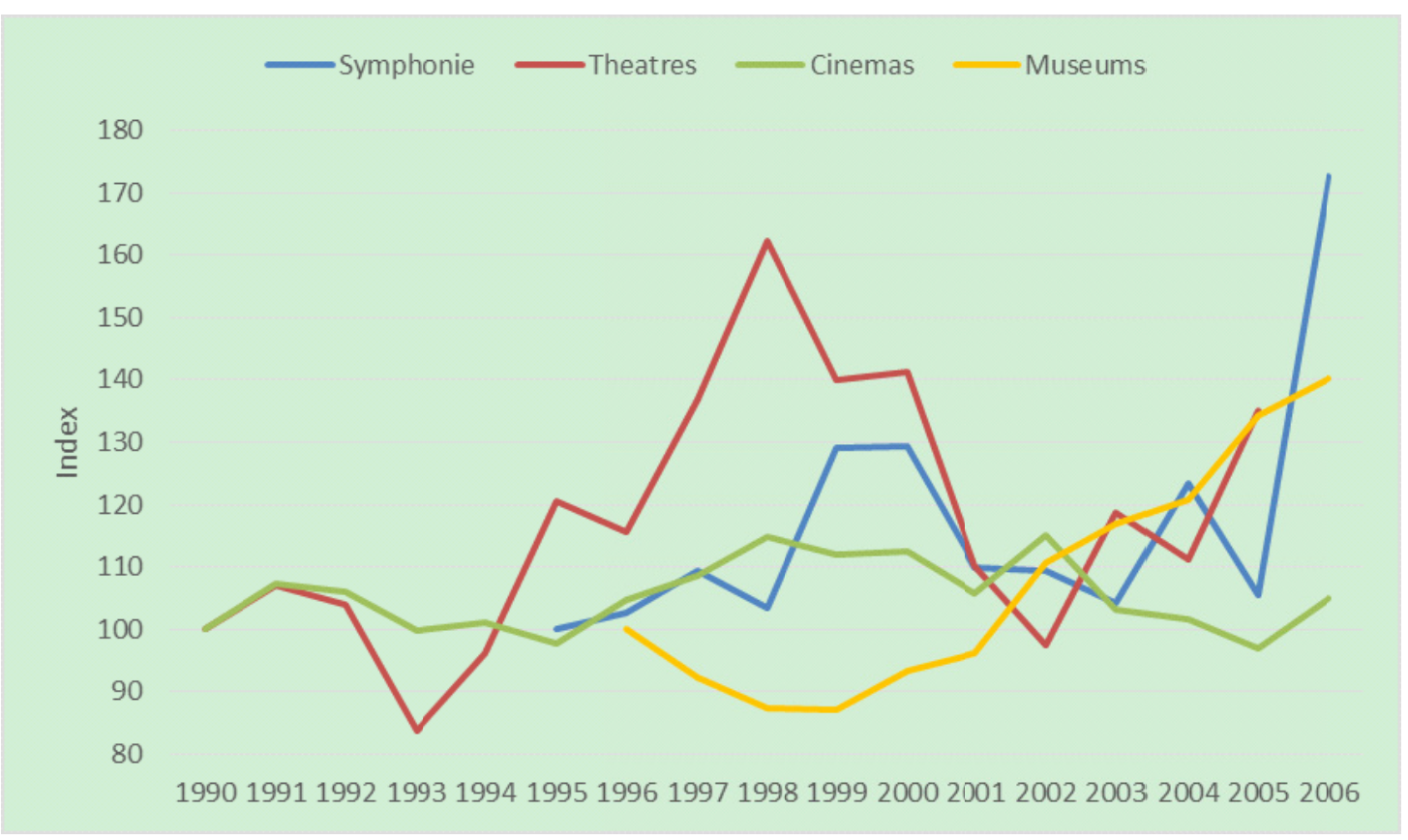

Figure 2. Number of guests in theatres, cinemas, museums and at concerts in the capital area from 1990-2006

Source: Statistics Iceland.

Changes in household preference in favour of access over amenity values can also be responsible for the developments mentioned above. Cities offer better access to a variety of services, such as education, cultural events and health care than rural areas. According to data from Statistics Iceland, demand for cultural events has been rising for the past decade (Figure 2). Icelanders visit museums, theatres, and cinemas more often than is the norm in other Nordic countries. Such institutions are primarily located in the capital region of Iceland. Moreover, the demand for museums, concerts, and theatres in Iceland increased between the years 1995 and 2006 while cinema guests have become fewer in recent times. Museum visits per 1,000 inhabitants increased relatively by $59 \%$ between those years and theatre visitors per 1,000 inhabitants by $25 \%$, whereas the number of cinema seats per 1,000 inhabitants fell by $31 \%$. Museums and theatres are probably better economic indicators for culture than cinemas, since closer substitutes to cinemas, such as video-on-demand (VOD) and supply of films and videos on the internet, have been entering the Icelandic market in recent years. Furthermore, visits and visitors are better economic indicators than numbers of seats.

Demographic changes might play a role in the development of spatial disparity in housing prices as suggested in a recent paper (Takáts, 2012) where an aging population seems to reduce housing prices. According to Krainer (2005), aging can exert negative pressure on housing prices, since housing demand is driven by a working age population, while retired people fuel the supply side when their houses come on the market, for example as a consequence of death or growing need for elderly care. In 1990, the average age was 31.8 years in rural regions and 33.4 in the capital area. In 2005, the figures were 35.4 in rural 
districts and 35.5 in the capital area. The gender balance, however, was 0.94 in the rural area in the year 1991 and 0.945 in 2005. In the capital area, those numbers were 1.04 and 1.03 respectively. Moreover, a significant variance is detectable when comparing municipalities in this context (Table 1).

Thus, the present paper will try to determine the marginal effect of structural change on the growing spatial disparity of housing prices and the presence of changed preferences for access over amenity values, while including relevant variables such as demographic changes, income and housing characteristics.

\section{The Empirical Model}

The hedonic price model is highly related to the bid-rent curve since it is a market equilibrium function where each point represents one equilibrium point; that is, a function of market supply and market demand (i.e. bid-rent function). The hedonic price model is the most frequently used approach in research on the spatial disparity of housing prices within the economic literature (Cunningham, 2006; Gibbons \& Machin, 2005; Haurin \& Brasington, 1996; Kiel \& Zabel, 1996; McMillen, 2003, pp. 289-290; Plaut \& Plaut, 1998, p. 213; Tyrvainen \& Miettinen, 2000). The model introduces housing and lot characteristics to the standard analysis of the bid-rent curve (Cunningham, 2006, p. 6; Tyrvainen \& Miettinen, 2000 , p. 206) such as house age, size of garden, number of rooms, garages, bathrooms, building materials, that generate the explanatory variables of the empirical model. The approach of the present paper will follow the hedonic model framework. Other alternative approaches, such as the standard repeat sales (McMillen, 2003, p. 290) and Fourier repeat sales approaches (McMillen, 2003, p. 291) could have been implemented if the data sample had been suitable.

According to Fujita (1989, pp. 6, 16) and Kiel and McClain (1995a, pp. 314-315) the general context from the basic model, $h(I, T, d, x, l)$, can be derived through a log linear utility function into an equation of the following form in its simplest version:

$$
\text { Eq. } 1 \quad h(d)=A e^{-b d}
$$

where $h$ is the housing price, $d$ is the distance between the land location and the CBD, and $A$ and $b$ are positive constants. By taking the natural logarithm of both sides, Eq. 1 becomes

$$
\text { Eq. } 2 \ln h(d)=\ln A-b d
$$

This equation has been used extensively in housing price research based on the hedonic price model. Furthermore, it is routinely used in the field of housing price research regarding relevant dependent variables, as can be seen, e.g. in Cunningham (2006, p. 6), Gibbons and Machin (2005, p. 152), McMillen (2003, pp. 289, 293), Haurin and Brasington (1996, p. 356), Kiel and Zabel (1996, p. 148) and Kiel and McClain (1995a, p. 319; 1995b, p. 248). The equation is a non-linear relationship of semi-logarithmic type. Instead of estimating a simple model as follows: 


$$
\text { Eq. } 3 \quad \ln h_{i t}=\alpha_{i}+d_{i t} \beta_{1}+\varepsilon_{i t}
$$

economists frequently implement an extended model:

$$
\text { Eq. } 4 \quad \operatorname{lnh}_{i t}=\alpha_{i}+d_{i t} \beta_{1}+c z^{\prime}{ }_{i t}+\varepsilon_{i t}
$$

where $z_{i t}^{\prime}$ is a vector of relevant additional explanatory variables that the model has to control for and $c$ is a vector of coefficients. Thus, it is reasonable to apply the following empirical model:

$$
\text { Eq. } 5 \quad \operatorname{lnh}_{i t}=\alpha_{i}+d_{i t} \beta_{1}+z^{\prime}{ }_{i t} \beta_{2}+v^{\prime}{ }_{i t} \beta_{3}+\varepsilon_{i t}
$$

where the natural logarithm of the housing price, $h$, is dependent on the distance, $d$, to the capital area, or CBD, several other explanatory variables, $z^{\prime}$, dummy variables, $v^{\prime}$, and relevant residuals, $\varepsilon$, of every municipality, $i$, in every single period, $t$. The selection of the explanatory variables which will be controlled for in the present model was based on similar studies (Cunningham, 2006; Gibbons \& Machin, 2005; Haurin \& Brasington, 1996; Kiel \& Zabel, 1996; McMillen, 2003, pp. 289-290; Plaut \& Plaut, 1998, p. 213; Tyrvainen \& Miettinen, 2000) and classified into several categories, that is: local economic factors, hedonic variables, demographic factors, and amenities. Thus I adopt what I believe to be a conceptually more attractive method than the standard hedonic approach. The characteristics of the hedonic model are included while other relevant spatial variation of local income, structural change, and demographic variables is added, as is done in other studies, apart from structural change (Butnic, 2011; Haurin and Brasington, 1996; Keskin, 2008). This is appropriate since the present data derive from an entire country instead of one urban area as is often the case where hedonic models are applied. This procedure, however, suits the purpose of the paper and the fact that spatial variation of local income and demographical variables is notable for the entire country of Iceland. Table 1 shows the entire list of variables. Housing prices tend to correlate with household income (De Bruyne \& Van Hove, 2006; McDonald \& Osuji, 1995). Demographic variables are local gender balance and average age. The gender balance varies between municipalities and can affect migration of men (Vífill Karlsson, 2013) and thus the housing market. Local average age can affect the housing market since the need for dwellings changes throughout the life cycle as mentioned earlier. The local primary industry could capture the effect of structural changes in Iceland that are traced to the increased share of services and knowledge-based industries. The service sector and knowledge-based industry tend to earn higher profits than primary industry and thus often pay higher wages or dividends, and generate more agglomeration economies. The wages have already been taken care of by the variable total income so the share of primary industry will to some extent reflect dividends and agglomeration economies.

As in an earlier paper (Karlsson, 2011) on Iceland, the presence of a town called Akureyri, approximately $300 \mathrm{~km}$ away from the capital city, makes the implementation of the traditional version of the empirical model inappropriate. Thus, a polycentric version, based on the work of Partridge, Rickman, Ali, and Olfert (2009, p. 451), is implemented.

$$
\text { Eq. } 6 \quad \operatorname{lnh}_{i t}=\alpha_{i}+s_{i t} \beta_{1}+u_{i t} \beta_{2}+e_{i t} \beta_{3}+z^{\prime}{ }_{i t} \beta_{4}+v^{\prime}{ }_{i t} \beta_{5}+\varepsilon_{i t}
$$




\section{Macrothink}

where $s, u$, and $e$ are three different travel distance variables: $s$ is the travel distance to Reykjavík for municipalities closer to Reykjavík than Akureyri, $u$ is the travel distance to Akureyri for municipalities closer to Akureyri than Reykjavík, and $e$ is the additional travel distance to Reykjavík for municipalities closer to Akureyri than Reykjavík. Let $a$ be the travel distance from all municipalities to Akureyri: if $d>a$, then $u=a$, otherwise $u=0$; and if $d<a$, then $s=d$, otherwise $s=0$. In order to determine whether proximity to the larger CBD, the capital city, is valuable to municipalities closer to Akureyri than to Reykjavík, additional variables were constructed as follows: if $d>a$, then $e=d-a$, otherwise $e=0$. A further argument for this model is to be found in a recent paper (Karlsson, 2011). Therefore, the several-period comparison of this model is suitable for the subject of this paper, where the difference between the coefficients for $s$ and $u$ detects the changes in preference for access over amenity values, ceteris paribus.

\section{Data}

Iceland is divided into 79 municipalities for the purpose of this paper which covers the entire period from 1990 to 2005, or at least one business cycle. Many municipalities were merged during this period. Therefore the data has been transformed into one identical sample of 79 municipalities completely comparable to the situation in the year 2006. The explanatory variables included in Eq. 6 are drawn from various sources, including the Commissioner of Inland Revenue, Statistics Iceland, and the Icelandic Road Administration. Information on housing prices, age and other relevant factors was received from the Iceland Property Registry. Data on road distances came from Fjölvís Publishing Company, originally collected by the Icelandic Road Administration, and information on population and total income was received from Statistics Iceland. The Commissioner of Inland Revenue was the primary source for total income. The national price index, collected from Statistics Iceland, was used to convert housing prices and total income into real terms. 
Table 1. Variable description and sample statistics

\begin{tabular}{|c|c|c|c|}
\hline Variable (acronym) & Description & Mean & $\begin{array}{l}\text { Standard } \\
\text { deviation }\end{array}$ \\
\hline Housing price (hopr) & Real price of houses, in Icelandic krónur. & $9,558,597$ & $4,875,671$ \\
\hline Travel time Reykjavík (ttre) & $\begin{array}{l}\text { Average travel time in minutes for each municipality doser to } \\
\text { Reykjavík than to Akureyri from the capital city, in absolute } \\
\text { terms. }\end{array}$ & 72.6 & 103 \\
\hline Travel time Akureyri (ttak) & $\begin{array}{l}\text { Average travel time in minutes for each municipality doser to } \\
\text { Akureyri than to Reykjavík from Akureyri, in absolute terms. }\end{array}$ & 43.4 & 78.2 \\
\hline Marginal travel time Reykjavík (ttrm) & $\begin{array}{l}\text { Average additional travel time in minutes from Reykjavík for } \\
\text { each municipality doser to Akureyri than to Reykjavík, in } \\
\text { absolute terms. }\end{array}$ & 79.9 & 119.7 \\
\hline Total Income (tinc) & Tota real income per capita, in thousands of Iœelandic krónur. & $2,020.30$ & 658.9 \\
\hline Housing age (hage) & Average age of houses sold, in absolute terms. & 28.9 & 15.9 \\
\hline Housing size (hsiz) & Average size of houses sold, in square meters. & 143.1 & 69.2 \\
\hline Number of dwellings (honr) & Average number of dwellings in each house. & 1.019 & 0.103 \\
\hline Dwelling's floor (hofl) & $\begin{array}{l}\text { Average number of floor, reflecting the dwellings position in } \\
\text { heights from the ground. }\end{array}$ & 1.653 & 0.653 \\
\hline Rooms pr. dwelling (horo) & Average number of rooms per dwelling. & 3.366 & 1.035 \\
\hline House building material wood (hom6) & Share of dwellings where wood is outwall's building material. & 0.205 & 0.257 \\
\hline Balcony size (hoba) & Average size of balcony, in square meters. & 2.361 & 3.605 \\
\hline Parking/Garage (hopa) & $\begin{array}{l}\text { Share of dwellings where either parking place or any type of } \\
\text { garage is included. }\end{array}$ & 0.443 & 0.293 \\
\hline Lot size (holo) & Average size lots, in square meters. & 537.3 & 410.8 \\
\hline Population (popu) & Municipality population, in absolute terms. & $3,360.60$ & $11,779.60$ \\
\hline Akureyri (akur) & $\begin{array}{l}\text { Dummy variable for a municipality outside the capital area with } \\
\text { an unusually populous centre: } 1 \text { for Akureyri and } 0 \text { for all other } \\
\text { municipality. }\end{array}$ & 0.013 & 0.112 \\
\hline Tunnel (tunn) & $\begin{array}{l}\text { Dummy variable of large transportation improvement. } 1 \text { for } \\
\text { Whale fjord tunnel. }\end{array}$ & 0.21 & 0.408 \\
\hline Aluminum East Coast (alea) & $\begin{array}{l}\text { Large scale local investment. New aluminium smelter on the } \\
\text { east coast of Iceland. }\end{array}$ & 0.004 & 0.066 \\
\hline Gender balance (tgen) & Local gender balance. Number of women divided by men. & 0.907 & 0.093 \\
\hline Average age (page) & Local population average age. & 34.519 & 3.198 \\
\hline Primary industry relative size (prip) & Local primary industry relative employment. & 0.292 & 0.201 \\
\hline
\end{tabular}

The data series were annual averages, except for population and road distance, which were point estimates. Data on population is from 1 December every year and the data on road distance 1 January every year. The data series were originally classified spatially by municipalities, except for the data on road distance, which were classified by localities. Therefore, the data series on road distance were transformed from localities into municipalities.

The data used to represent distance is the travel time between the centre of each municipality and the centre of the two CBDs, expressed in minutes. As regards travel time, transportation improvements include both shortening of road distances and improved road quality as a result of paving gravel roads. The calculation was as follows: $t_{i t}=\left(\pi_{i t} 60 \% 90+\left(1-\pi_{i t}\right) 60 / 70\right) d_{i t}$, where $t_{i t}$ is travel time, $d_{i t}$ is travel distance and $\pi_{i t}$ is the share of paved road between each 
municipality and the CBD. Municipality is identified by $i$ and time by $t$. Note that average speed is assumed to be 90 kilometres per hour on a paved road and 70 on gravel.

The value of the dummy variable for Hvalfjörður tunnel was also added to the present model (Table 1). It is "one" from the year 1998 for the four municipalities closest to the tunnel on the north side but "zero" in all other cases. The tunnel shortened the travel distance to Reykjavík for municipalities north of the tunnel. The four municipalities are within a range of approximately 50 kilometres to the north of the tunnel. One could also argue that this variable stands for the impact of the aluminium smelter at Grundartangi industrial park - which is close to the tunnel on the north side - because it was launched the very same year, in 1998. Since the tunnel reduced travel time between many municipalities and the capital city, its impact has been generated in the explanatory variable for travel time. If this dummy variable has a significant impact on housing prices it must be traced to the other major development in the area that year - the start of the aluminium smelter at Grundartangi industrial park.

The local gender balance is number of women divided by men. Local average age was calculated for every municipality. The relative size of local primary industry was found by calculating the share of the industry in total employment.

In many instances, the averages and the standard deviations of the explanatory variables, as well as of the dependent variable, show considerable variation (Table 1). The standard deviation of housing prices is approximately $1 / 2$ of the mean and of road distance more than $3 / 4$ of the mean. This is evidence of significant differences that show potential for robust explanations. However, this panel data sample is unbalanced since observations for several values are missing.

\section{Results}

As explained in the discussion of the model in Section 3, the empirical model for testing the hypothesis is shown in Eq. 6. Along with the explanatory variables listed in Table 1, time dummy variables, one for each year, were also constructed and included in order to capture changes in all macro conditions, such as mortgage interest rates and GDP.

To estimate the development of the curve, reflecting the relationship of travel time to the local real price of houses among other relevant variables, as in Eq. 6, a random effect model was implemented, as argued in two earlier papers (Vifill Karlsson, 2007, 2011). A random effect model is more appropriate to the present analysis than a fixed effect model, as it includes both within and between variation of the data sample, while a fixed effect model returns only within variation (Hsiao, 2006; Verbeek, 2004). By the inclusion of both between and within variation, the estimated coefficient captures the value of the specific local divergence along with the pure distances.

In order to detect a development of the coefficients, especially of the distance gradient, the study includes an estimate of four different periods: 1990-1995, 1995-2000, 2000-2005, and, out of mere curiosity, the entire period, 1990-2005, as well. A Hausman test supported the suggestion of using a random effect model in all cases except in the estimation of the period 1990-1995 where it was neither able to support nor reject. 


\section{Macrothink}

International Journal of Regional Development

ISSN 2373-9851

2015, Vol. 2, No. 2

Initially, the estimations suffered from serial correlation for the period 1990-1995 and 1990-2005, which was sufficiently eliminated by a lagged variable of the residual, a method recommended by Wooldridge (2002, pp. 176-177). Furthermore, the presence of heteroskedasticity was addressed by running a robust estimator. Multicollinearity was not detected.

Endogeneity was tested against total income and average age. Total income can be endogenous since it can affect housing prices, while housing prices can affect total income as well, both through price level and price class selection; that is, low income workers tend to reside in regions or neighbourhoods if the housing is affordable, while high income households can afford expensive housing in attractive quarters. Average age can be endogenous since it can affect housing prices. However, housing prices, in turn, can affect average age as younger people cannot afford expensive housing because of lower income and assets than older people. Endogeneity was present only in the estimation for the period 2000-2005 and 1990-2005. Total income was the endogenous variable in the former estimation and average age in the latter. Theoretically, total income correlates with labour income. Furthermore, the percentage of elderly people in the local population should have an impact on total household income. Thus, the instrument variables for total income were labour income and percentage of the elderly in the local population. The population average age and share of the elderly correlate and were used here as instrument. The Sargan test rejected the hypothesis of weak instruments and in all cases returned the estimator lower than its critical value of 5.99 .

The results presented in Table 2 include parameter coefficients, z-values, number of observations, $\mathrm{R}^{2}$, and $\mathrm{t}$-statistics for a special test of serial correlation recommended by Wooldridge (2002, pp. 176-177). For simplicity, the estimations for time dummies are presented separately in the appendix. The results were as expected. The newer curve for Reykjavík and the nearest municipalities was steeper than the older curve, where the slope was -0.002 in the period 2000-2005 and only -0.001 in the period 1995-2000 (Table 2). That goes for Akureyri as well. 
Table 2. Relationship between housing prices and travel time from CBD. A random effect panel data model comparing two periods

\begin{tabular}{|c|c|c|c|c|}
\hline Variable (acronym) & 1991-1995 & $1995-2000$ & $2000-2005$ & $1991-2005$ \\
\hline Total household income (tinc) & $0.0002(1.26)$ & $0.000(1.28)$ & $0.0002(2.77)^{* *}$ & $0.0001(3.16)^{* *}$ \\
\hline Travel time to Reykjavík (ttre) & $-0.0008(-3.27)^{* * *}$ & $-0.001(-3.72)^{* * *}$ & $-0.0022(-4.72)^{* * *}$ & $-0.0014(-4.98)^{* * *}$ \\
\hline Travel time to Akureyri (ttak) & $-0.0008(-1.29)$ & $-0.001(-2.52)^{* *}$ & $-0.0018(-2.81)^{* *}$ & $-0.0017(-3.19)^{* * *}$ \\
\hline Additional travel time to Reykjavík (ttrm) & $-0.0001(-0.30)$ & $0.000(-0.24)$ & $0.0009(1.73)^{*}$ & $0.0002(0.79)$ \\
\hline Closer to Reykjavík than Akureyri (dmrl) & $0.1163(1.10)$ & $0.082(0.94)$ & $0.2580(1.74)^{*}$ & $0.0656(0.93)$ \\
\hline housing age (hage) & $-0.0085(-3.53)^{* * *}$ & $-0.010(-4.32)^{* * *}$ & $-0.0092(-5.28) * * *$ & $-0.0124(-6.95)^{* * *}$ \\
\hline housing size (hsiz) & $0.0013(7.36)^{* * *}$ & $0.003(8.48)^{* * *}$ & $0.0019(14.31)^{* * *}$ & $0.0019(9.08)^{* * *}$ \\
\hline Number of dwellings (honr) & $-0.4303(-1.28)$ & $-0.049(-0.22)$ & $-0.3844(-1.45)$ & $-0.1615(-1.08)$ \\
\hline Rooms per dwelling (horo) & $0.1297(3.95)^{* * *}$ & $0.060(1.86)^{*}$ & $0.0579(2.87)^{* *}$ & $0.0912(3.66)^{* * *}$ \\
\hline Wood house (hom6) & $0.1387(1.19)$ & $0.165(1.62)$ & $0.2290(2.19)^{* *}$ & $0.2159(2.89)^{* *}$ \\
\hline Balcony size (hoba) & $0.0151(1.86)^{*}$ & $0.015(2.08)^{* *}$ & $0.0051(0.90)$ & $0.0101(2.29)^{* *}$ \\
\hline Parking/garage (hopa) & $0.1881(2.53)^{* *}$ & $0.086(1.22)$ & $0.3305(3.92)^{* * *}$ & $0.1636(3.10)^{* *}$ \\
\hline Lot size (holo) & $0.0000(0.20)$ & $0.000(0.30)$ & $-0.0001(-0.76)$ & $0.0000(-0.14)$ \\
\hline Aluminium plant (alea) & & & $0.2323(2.16)^{* *}$ & $0.2571(3.34)^{* * *}$ \\
\hline Hvalfjörður tunnel (tun3) & & $0.055(1.08)$ & $0.1658(1.70)^{*}$ & $0.1387(3.51)^{* * *}$ \\
\hline Gender balance of local population (tgen) & $0.2806(0.53)$ & $0.164(0.40)$ & $-0.1498(-0.30)$ & $0.1958(0.61)$ \\
\hline Local population average age (page) & $0.0021(0.14)$ & $-0.017(-1.33)$ & $-0.0373(-2.83)^{* *}$ & $-0.0451(-4.01)^{* * *}$ \\
\hline Local primary industry relative employment (prip) & $-0.7154(-2.68)^{* *}$ & $-0.664(-3.20)^{* * *}$ & $-0.8143(-3.54)^{* * *}$ & $-0.4656(-2.84)^{* *}$ \\
\hline Lagged residual t-1 & $-0.0745(-0.76)$ & & & $0.1800(3.38)^{* * *}$ \\
\hline Constant & $15.3938(16.49)^{* * *}$ & $16.109(27.94)^{* * *}$ & $17.439(22.74)^{* * *}$ & $16.9386(32.40)^{* * *}$ \\
\hline $\mathrm{N}$ & 227 & 315 & 293 & 711 \\
\hline $\mathrm{R}^{2}$ within & 0.5449 & 0.5244 & 0.7226 & 0.6181 \\
\hline $\mathrm{R}^{2}$ between & 0.6309 & 0.7027 & 0.8102 & 0.6828 \\
\hline $\mathrm{R}^{2}$ overall & 0.6219 & 0.6484 & 0.7776 & 0.6709 \\
\hline Serial correlation, t-test & -1.94 & -1.27 & 0.13 & 0.24 \\
\hline Multicollinearity & No & No & No & No \\
\hline Heteroskedastis ity & Robust & Robust & Robust & Robust \\
\hline Sargan test 1 (p-value) & 0.081 & 0.167 & 0.01 & 0.072 \\
\hline Sargan test 2 (p-value) & 0.072 & 0.285 & 0.075 & 0.018 \\
\hline Hausman test for random effect model p-value (Chi-sq) & Not testable & $0.1776(23.35)$ & $0.1403(24.47)$ & $0.0118(50.19)$ \\
\hline Panel data sample & Unbalanced & Unbalanced & Unbalanced & Unbalanced \\
\hline
\end{tabular}

Dependent variable housing prices. $*$ significant at the $10 \%$ level; $* *$ significant at the $5 \%$ level; $* * *$ significant at the $1 \%$ level. Population average age was endogeneous in the model 1991-2005 and successly solved by an instrument variable and total income in the model 2000-2005. Sargan test lower than 0,05 is not sufficient. Hausman test lower than 0,01 is not sufficient.

The curve became steeper while the population increased in the capital area, as mentioned earlier. Thus, the higher relative housing price of the capital area is caused by its rising attractiveness. This is true for Akureyri as well. The analysis included the spatial diversity of other relevant economic factors such as total income, population, housing age, industrial structure, demographic variables, and several known large-scale investments. It is reasonable to believe, therefore, that this is evidence of changed consumer preferences in Iceland, for access over amenities.

Furthermore, the results suggest that a rapid industrial structural change during the past decade has fuelled the spatial disparity of housing prices in Iceland. As argued earlier, the latest economic expansion in Iceland was primarily driven by knowledge-based industry and a higher level of education among the labour force. This, in turn, was reflected by the growth 
of the number of people in highly skilled occupations in the capital area. The significant negative sign of the coefficient for primary industry reflects the fact that the higher its share, the lower the housing prices - or the larger the share of knowledge-based industry and the service sector, the higher the housing prices. This is probably due to a greater marginal return than yielded by primary industry. Note that the marginal impact seems to be increasing throughout the period.

Aging had a negative impact on the spatial disparity of housing prices, but this was only significant in the last period. It suggests that aging is of growing concern since it is beginning to negatively affect economic variables such as housing prices.

Almost every other variable had the expected impact on housing prices. Housing size, number of rooms per dwelling, presence of balconies, garages and parking places had a positive impact on housing prices while housing age had a negative impact.

Note that the impact of the large-scale investment on the east coast is only relevant for one year since it was implemented in 2004. The aluminium smelter on the west coast was started in 1998 as noted earlier. In this case, it is better to look at the coefficient estimation for the entire period to detect long-term impact. Interestingly, it is noted that the investment on the east coast seems to have a greater impact than that on the west coast. However, it can be argued that the dummy variable for large-scale investments only returns a partial impact of the smelter since it most likely will raise total household income as well as decreasing average age. The total impact of the large-scale investment could be found by running another estimation which detects the marginal impact of the aluminium smelter on total income and average age. Subsequently this could be run through the result of the present estimation of marginal impact of total income and average age on housing prices.

The estimated slopes of the bid-rent curves of the present study, in the range of $0.01 \%-0.02 \%$, are not entirely in line with results from several other studies. McDonald and Osuji (1995, p. 261 ) found it to be approximately $1 \%$ for the city of Chicago. A $0.7 \%$ distance gradient was among Cunningham's (2006, p. 18) results for the CBD of Seattle. Tyrvainen and Miettinen (2000, p. 215) concluded that housing value decreases by $0.11 \%$ for every $1 \%$ distance in kilometres away from the centre of the Salo district in Finland. De Bruyne and Van Hove (2006) came up with a rather different figure from Belgium, with a gradient somewhere between $0.001 \%$ and $0.002 \%$. The present figure for Iceland is between other published results; higher than the Belgian result and lower than almost all other results. This might be due to the fact that the studies for Iceland and Belgium comprise data for an entire country, while the rest of the studies mentioned above used data for a conurbation area only. The difference of the distance gradient in Iceland and Belgium is worth a discussion. This is much steeper in Iceland than in Belgium. The reason is probably that population density is much lower in Iceland (3.00) than Belgium (339.71) - out of 192 countries, Iceland ranks as number 189 and Belgium as 16. Furthermore, there is a relatively larger difference between the size of cities and towns in Iceland than in Belgium. According to Statistics Iceland, there were 105 towns and villages in Iceland in 2005 and most of them had fewer than 500 inhabitants. The largest urban area in Iceland, Reykjavík and the adjacent towns, had 
approximately 186,000 inhabitants in 2005. The second largest urban area, Akureyri, located on the north coast (Figure 1), had about 16,500 inhabitants that year. The third, fourth and the fifth largest are Keflavík which had approximately 8,000 inhabitants in 2005, Akranes 5,800 and Selfoss 5,700 - all located in the intermediate area (Figure 1). Note that the second largest urban area in Iceland has a population comprising less than 10\% of the largest urban area. The largest city in Belgium is Antwerp with a population of about 466,000 inhabitants in 2007, the second largest Ghent approximately 235,000 and the third Charleroi 202,000. Four other cities had more than 100,000 inhabitants in Belgium that year. The second largest city in Belgium has more than $50 \%$ of the population of the largest one. Therefore, it is more appropriate for the entire country of Iceland to be treated as one monocentric city - as indeed the framework of the bid-rent curve assumes - than Belgium, and thus returning a steeper distance gradient from the largest urban area to the smallest. For the sake of precaution, the data for the entire country of Iceland was implemented as a polycentric city of two layers in the present study; Reykjavík as the top layer and Akureyri as the second one. Furthermore, it can be argued that Iceland is an exceptional case for urban studies since it has one dominant city and is geographically isolated. Thus it does not generate possible disturbances from other strong metropolitan areas.

Table 3. Size and location of towns in Iceland - December 2005

\begin{tabular}{|l|r|r|r|r|r|}
\hline Town's population & Total & $\begin{array}{l}\text { South } \\
\text { coast }\end{array}$ & $\begin{array}{l}\text { West } \\
\text { coast }\end{array}$ & $\begin{array}{l}\text { North } \\
\text { coast }\end{array}$ & $\begin{array}{l}\text { East } \\
\text { coast }\end{array}$ \\
\hline Population of 0-500 & 60 & 13 & 19 & 18 & 9 \\
\hline Population 501-1,000 & 17 & 5 & 3 & 4 & 3 \\
\hline Population 1,001-10,000 & 25 & 13 & 5 & 4 & 5 \\
\hline Population $>10,000$ & 4 & 3 & 0 & 1 & 0 \\
\hline Total & 105 & 34 & 27 & 27 & 17 \\
\hline
\end{tabular}

\section{Conclusion}

The relationship between housing prices and distance from the capital area of Iceland, a thinly populated region with one small city and several small towns, is statistically significant. I have shown that this relationship has become increasingly stronger recently, most likely because of increased preference for access over amenities. Aging, and especially structural changes, have had the effect of increasing spatial variation in housing prices in Iceland as well. The increased share of power intensive industry in Iceland has also fuelled spatial variation in housing prices. These are the results when correcting for regional disparity in total income, population, and housing age, as well as several other relevant explanatory variables. 


\section{Macrothink Institute ${ }^{\text {TM }}$}

The latest economic expansion in Iceland was driven more by knowledge-based industry than former expansions were. Since knowledge-based industry and the service sector tend to return a higher marginal profit than primary industry, this results in a higher marginal factor income and agglomeration economies. Furthermore, structural changes can affect housing prices through other factors than wages.

These results are considerably robust, as they are based on a large data series of all 79 municipalities of Iceland from 1990 to 2005.

\section{References}

Cunningham, C. R. (2006). House price uncertainty, timing of development, and vacant land prices: Evidence for real options in Seattle. Journal of Urban Economics, 59(1), 1-31.

Fujita, M. (1989). Urban economic theory: Land use and city size. Cambridge: Cambridge University Press.

Fujita, M., \& Thisse, J. F. (2002). Economics of agglomeration: Cities, industrial location, and regional growth. Cambridge: Cambridge University Press.

Gibbons, S., \& Machin, S. (2005). Valuing rail access using transport innovations. Journal of Urban Economics, 57(1), 148-169.

Haurin, D. R., \& Brasington, D. (1996). School quality and real house prices: Inter- and intrametropolitan effects. Journal of Housing Economics, 5(4), 351-368.

Hsiao, C. (2006). Panel data analysis-Advantages and challenges. IEPR Working Papers, Institute of Economic Policy Research (IEPR).

Jónsson, G., \& Magnússon, M. S. (1997). Hagskinna. Reykjavík: Statistics Iceland.

Karlsson, V. (2007). Modern industrial structure and development of house price spatial disparity: A general case for Iceland-a large but thinly populated European country. Bifrost Journal of Social Science, 1, 96-116.

Karlsson, V. (2011). The Relationship of Housing Prices and Transportation Improvements: Location and Marginal Impact. Spatial Economic Analysis, 6(2), 223-241.

Karlsson, V. (2013). Interregional Migration and Transportation Improvements in Iceland. International Regional Science Review, 1-24.

Kiel, K. A., \& McClain, K. T. (1995a). The effect of an incinerator siting on housing appreciation rates. Journal of Urban Economics, 37(3), 311-323.

Kiel, K. A., \& McClain, K. T. (1995b). House prices during siting decision stages: The case of an incinerator from rumor through operation. Journal of Environmental Economics and Management, 28(2), 241-255.

Kiel, K. A., \& Zabel, J. E. (1996). House price differentials in U.S. cities: Household and neighborhood racial effects. Journal of Housing Economics, 5(2), 143-165. 


\section{Macrothink}

International Journal of Regional Development ISSN 2373-9851 2015, Vol. 2, No. 2

Krainer, J. (2005). Housing markets and demographics FRBSF Economic Letter (Vol. No. 2005-21): Federal Reserve Bank of San Francisco.

McCann, P. (2001). Urban and regional economics. Oxford: Oxford University Press.

McDonald, J. F., \& Osuji, C. I. (1995). The effect of anticipated transportation improvement on residential land values. Regional Science and Urban Economics, 25(3), 261-278.

McMillen, D. P. (2003). The return of centralization to Chicago: using repeat sales to identify changes in house price distance gradients. Regional Science and Urban Economics, 33(3), 287-304.

Partridge, M., D. , Rickman, D., S. , Ali, K., \& Olfert, M. R. (2009). Do new economic geography agglomeration shadows underlie current population dynamics across the urban hierarchy? Papers in Regional Science, 88(2), 445-466.

Plaut, P. O., \& Plaut, S. E. (1998). Endogenous identification of multiple housing price centers in metropolitan areas. Journal of Housing Economics, 7(3), 193-21 7.

Takáts, E. (2012). Aging and house prices. Journal of Housing Economics, 21(2), 131-141. http://dx.doi.org/10.1016/j.jhe.2012.04.001

Tyrvainen, L., \& Miettinen, A. (2000). Property prices and urban forest amenities. Journal of Environmental Economics and Management, 39(2), 205-223.

Verbeek, M. (2004). A guide to modern econometrics (2 nd ed.). West Sussex: John Wiley \& Sons, Ltd.

Wooldridge, J. M. (2002). Econometric analysis of cross section and panel data. Cambridge: The MIT Press.

De Bruyne, C., \& Van Hove, J. (2006, June). Explaining the spatial variation in housing price: An economic geographic approach. Paper presented at the ECOMOD urban and regional modeling, Brüsselles, Belgium. 


\section{Macrothink}

International Journal of Regional Development

ISSN 2373-9851

2015, Vol. 2, No. 2

\section{Appendix}

This appendix contains an overview of time dummies from present models. Hopefully, the paper has been made clearer by presenting the results in two separate tables.

Table 4. The estimates for time dummies

\begin{tabular}{|c|c|c|c|c|}
\hline Variable (acronym) & $1991-1995$ & $1995-2000$ & $2000-2005$ & $1991-2005$ \\
\hline \multicolumn{5}{|l|}{ Time dummy for 1990 (tdum10) } \\
\hline Time dummy for 1991 (tdum11) & $-0.0776(-2.39) * *$ & & & $-0.1015(-3.30) * * *$ \\
\hline Time dummy for 1992 (tdum12) & $-0.0126(-0.42)$ & & & $-0.0205(-0.72)$ \\
\hline \multicolumn{5}{|l|}{ Time dummy for 1993 (tdum13) } \\
\hline Time dummy for 1994 (tdum14) & $0.0530(1.41)$ & & & $0.0871(2.34)^{* *}$ \\
\hline Time dummy for 1995 (tdum15) & $0.0302(0.98)$ & & & $0.0709(2.10)^{* *}$ \\
\hline Time dummy for 1996 (tdum16) & & $-0.061(-1.61)$ & & $0.0419(1.26)$ \\
\hline Time dummy for 1997( tdum17) & & $-0.008(-0.21)$ & & $0.0818(2.24)^{* *}$ \\
\hline Time dummy for 1998 (tdum18) & & $-0.039(-0.78)$ & & $0.0493(0.97)$ \\
\hline Time dummy for 1999 (tdum19) & & $0.014(0.28)$ & & $0.1025(2.24)^{* *}$ \\
\hline Time dummy for 2000 (tdum20) & & $0.018(0.35)$ & & $0.0991(2.01)^{* *}$ \\
\hline Time dummy for 2001 (tdum21) & & & $-0.0449(-1.40)$ & $0.0831(1.51)$ \\
\hline Time dummy for 2002 (tdum22) & & & $-0.0719(-1.94)^{*}$ & $0.0660(1.07)$ \\
\hline Time dummy for 2003 (tdum23) & & & $0.0624(1.69)^{*}$ & $0.1890(2.87)^{* *}$ \\
\hline Time dummy for 2004 (tdum24) & & & $0.0994(2.40)^{* *}$ & $0.2405(3.16)^{* *}$ \\
\hline Time dummy for 2005 (tdum25) & & & $0.2126(3.69)^{* * *}$ & $0.3932(4.55)^{* * *}$ \\
\hline
\end{tabular}

\section{Copyright Disclaimer}

Copyright for this article is retained by the author(s), with first publication rights granted to the journal.

This is an open-access article distributed under the terms and conditions of the Creative Commons Attribution license (http://creativecommons.org/licenses/by/3.0/). 